\title{
Expression of Mycoplasma pulmonis Antigens in Escherichia coli
}

\author{
Satoshi KUNITA, Eiji TERAIA, Akira GHODA, Yoshinori SAKURAI*, \\ Hirokazu SUZUKI*, Akira TAKAKURA**, and Naoko KAGIYAMA**
}

\begin{abstract}
Department of Laboratory Animal Science, School of Hygienic Science, Kitasato Univrsity, Kitasato, Sagamihara, 228, Japan, ${ }^{*}$ Wakamoto Pharmaceutical Co., Ltd., 378 Kanade, Ooi-cho, Ashigarakami-gun, Kanagawa, 258, and ${ }^{* *}$ Central Institute for Experimental Animals, 1430 Nogawa, Miyamae, Kawasaki, 213.
\end{abstract}

(Received 4 November 1988/Accepted 8 March 1989)

\begin{abstract}
The expression of Mycoplasma pulmonis antigen in Escherichia coli was investigated by cloning genomic DNA derived from $M$. pulmonis $\mathrm{m} 53$, and the DNA fragment participating in antigen expression was identified. When the DNA library of $M$. pulmonis was screened by colony immunoassay using anti-M. pulmonis serum, 10 recombinant clones expressing seroreactive antigens were obtained. The recombinant plasmids isolated from these clones included 3.7 6.5 kilobase pair (kbp) DNA inserts, while all clones contained a common 2. 3-kbp DNA fragment. Subcloning of initial DNA inserts showed that the common 2. 3-kbp fragment is essential for antigen expression. Moreover, antiserum against the recombinant antigen generated from the 2. 3-kbp DNA fragment recognized a native $M$. pulmonis antigen. The reactivity of this antiserum was absorbed specifically with $M$. pulmonis. These results suggest that the cloned 2.3-kbp DNA fragment codes an antigen specific to $M$. pulmonis.
\end{abstract}

In the previous study [5], we analyzed genomic DNA of typical rodent mycoplasmas, Mycoplasma pulmonis, $M$. arthritidis and $M$. neurolyticum, and demonstrated that the DNA sequences of these species possess a high degree of species specificity. In addition, it was revealed that genomes of $M$. pulmonis strains are closely related $[5,12]$. These findings strongly suggest the existence of DNA fragments that are specific to $M$. pulmonis species. Therefore, the authors attempted to clone a DNA fragment which codes a species-specific antigen of $M$. pulmonis in order to isolate a DNA fragment specific to this species. In this paper, we report the characteristics of $M$. pulmonis antigen expressed in Escherichia coliby the recombinant DNA technique and the characteristics of the DNA fragment which codes this antigen.

\section{Materials and Methods}

Organisms and culture conditions : $M$. pulmonis $\mathrm{m} 53, M$. arthritidis PG 6, and $M$. neurolyticum Type A were used for DNA extraction and antigen preparation. The sources and culture conditions have been described previously [5]. E. coli JM 109 was cultured in LB medium [7] at $37^{\circ} \mathrm{C}$, and used as the recipient for the plasmid vector pUC 19 (Takara Shuzo Co., Kyoto, Japan) [15].

Preparation of antisera : Anti-M. pulmonis serum was produced in a rabbit (Japanese white, female) by biweekly intravenous injections of sonicated M. pulmonis antigens. Three hundred micrograms of protein was used for each injection. Antiserum taken after the third injection was absorbed for $12 \mathrm{hr}$ at $4{ }^{\circ} \mathrm{C}$ with intact $E$. coli JM 109 carryring pUC 19 at a concentration of $1 \times 10^{11} \mathrm{E}$. coli cells per $\mathrm{ml}$ of 
serum, before it was used for colony immunoassay and Western blot analysis.

Antiserum against recombinant antigens was produced in a rabbit (Japanese White, female) by immunization with an ammonium sulphate precipitate of a lysate from the recombinant $E$. coli clone. The $E$. coli cells were suspended in 0.1 Mcarbonate-bicarbonate buff-

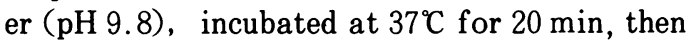
sonicated. After precipitation with $67 \%$ ammonium sulphate, the precipitates were dissolved in phosphate buffered saline (PBS) and dialyzed with PBS. A rabbit was immunized with biweekly intravenous injectons of $200 \mu \mathrm{g}$ of protein. After the fourth injection, the antiserum was taken, purified with an affinity column prepared by coupling $M$. pulmonis lysate to Sepharose 4 B (Pharmacia, Sweden), then absorbed with intact $E$. coli carrying pUC 19 at a concentration of $1 \times 10^{10} \mathrm{E}$. coli cells per $\mathrm{ml}$ of serum for $12 \mathrm{hr}$ at $4^{\circ} \mathrm{C}$.

All animals used for immunization were found to be free of antibodies against $M$. pulmonis, $M$. arthritidis, and $M$. neurolyticum when their preimmune sera were examined by an enzyme-linked immunosorbent assay using protein A (P-ELISA) [10].

Construction of the DNA library : Genomic DNA from $M$. pulmonis was extracted and purified as previously described [5]. M. pulmonis DNA was partially digested with HindIII (Nippon Gene Co., Toyama, Japan) to an average size of 3 to 9 kilobase pairs (kbp), then ligated to plasmid vector pUC 19 with T4 DNA ligase (Takara Shuzo). Before the ligation, the vector DNA was digested with HindIII and dephosphorylated with bacterial alkaline phosphatase (Takara Shuzo) . E. coli JM 109 cells were transformed with the ligation mixture by the $\mathrm{CaCl}_{2}$ procedure [7]. Recombinant transformants were selected on LB agar plates containing $50 \mu \mathrm{g}$ of ampicillin per $\mathrm{ml}, 0.1 \mathrm{mM}$ isopropyl- $\beta-\mathrm{D}$-thiogalactopyranoside (IPTG), and $40 \mu \mathrm{g}$ of 5 -bromo-4-chloro-3-indolyl- $\beta$ $\mathrm{D}$-galactoside (X-gal) per $\mathrm{ml}$.

Colony immunoassay : To screen the clones producing $M$. pulmonis antigens, colony immunoassay was performed by a modification of the method of Helfman et al. [2]. White colonies carrying recombinant plasmids were replica plated on LB agar containing ampicillin, IPTG and $\mathrm{X}$-gal. After incubation overnight at $37^{\circ} \mathrm{C}$, the colonies were transferred to nitrocellulose filters (Toyo Co., Tokyo, Japan) and lysed with chloroform vapor. These filters were immersed in a blocking solution [50 mM Tris$\mathrm{HCl}, \mathrm{pH} 7.5 / 150 \mathrm{mM} \mathrm{NaCl} / 5 \mathrm{mM} \mathrm{MgCl}_{2} / 1 \%$ bovine serum albumin (BSA) $/ 1 \mu \mathrm{g}$ of deoxyribonuclease I (Sigma Chemical Co., Louis, Mo.) per $\mathrm{ml} / 40 \mu \mathrm{g}$ of lysozyme (Sigma Chemical Co.) per ml ] for $1 \mathrm{hr}$ at $37^{\circ} \mathrm{C}$, rinsed in PBS, and incubated for $1 \mathrm{hr}$ at $37^{\circ} \mathrm{C}$ with anti-M. pulmonis serum ( $1: 200$ dilution in PBS containing $0.1 \% \mathrm{BSA})$. The filters were washed 3 times with $\mathrm{PBS}$ and reacted with horseradish peroxidase-conjugated protein A (HRPO-protein A) for $1 \mathrm{hr}$ at $37^{\circ} \mathrm{C}$. After being washed 3 times with PBS, the filters were developed in substrate buffer $(50 \mathrm{mM}$ Tris- $\mathrm{HCl}, \mathrm{pH} 7.2 / 0.3$ $\mathrm{mg}$ of $3.3^{\prime}$-diaminobenzidine per $\mathrm{ml} / 0.03 \%$ $\mathrm{H}_{2} \mathrm{O}_{2}$ ).

Western blot analysis : Transformants and mycoplasmas were solubilized by boiling for 5 min in $2 \%$ sodium dodecyl sulfate (SDS) $/ 5 \% 2-$ mercaptoethanol/10\% glycerol $/ 62.5 \mathrm{mM}$ Tris $-\mathrm{HCl}, \mathrm{pH}$ 6.8. Samples containing $15 \mu \mathrm{g}$ of $\mathrm{pr}-$ oteins were electrophoresed $(20 \mathrm{~mA} / \mathrm{gel}, 90 \mathrm{~min})$ on a $12 \%$ polyacrylamide gel according to the method of Laemmli [6]. Proteins separated on the gel were transferred electrophoretically to a nitrocellulose filter $(42 \mathrm{~V}, 2 \mathrm{hr})$ by the method of Towbin et al. [11]. After treatment with PBS containing $3 \%$ BSA overnight at $4{ }^{\circ} \mathrm{C}$, the blots were reacted with anti- $M$. pulmonis serum or anti-recombinant antigen serum. Antibody binding was detected with HRPOprotein A as described for colony immunoassay.

DNA analysis of recombinant clones: The restriction fragments of the recombinant plasmids were analyzed by agarose gel electrophoresis. Plasmid DNA was isolated from the recombinant $E$. coli by the alkaline lysis method [1] and digested with the appropriate restriction endonuclease. The digested DNA was electrophoresed on a $1 \%$ agarose gel in 40 $\mathrm{mM}$ Tris-acetate $/ 1 \mathrm{mM}$ ethylene diamine tetraacetate, $\mathrm{pH}$ 8.0. DNA fragments in the agarose gel were visualized by ethidium bromide staining. HindIII-digests of $\lambda$ phage DNA (Pharmacia) were used for DNA size markers.

The 2.3-kbp HindIII-fragment isolated from a recombinant plasmid was used as a probe for Southern hybridization. The probe was recovered from a low-meltingpoint gel by the method of Wieslander [13] and labeled with $\left[\alpha-{ }^{32} \mathrm{P}\right]$ 
deoxy cytidine triphosphate by the multiprime DNA labeling system (Amersham, England). Labeled probe was denatured by boiling for $5 \mathrm{~min}$ and quenching on ice, then used immediately for hybridization. HindIII-digests of recombinant plasmid DNA separated in an agarose gel were transferred to a nitrocellulose filter by the method of Southern [9]. The filter was hybridized with $5 \mathrm{ng} / \mathrm{ml}$ of ${ }^{32} \mathrm{P}$-labeled probe, washed, and autoradiographedas described previously [5].

Subcloning was carried out by HindIII-digestion of the initial clones, followed by selfligation. The subclones were analyzed for DNA inserts by agarose gel electrophoresis and for M. pulmonis antigen expression by Western blotting as described above.

Absorption of anti-recombinant antigen serum : Anti-recombinant antigen serum was absorbed with intact organisms of M. pulmonis, $M$. arthritidis, $M$. neurolyticum, recombinant $E$. coli, and control $E$. colicarrying pUC 19 at a concentration of $2 \mathrm{mg}$ (wet weight) of organisms per $\mathrm{ml}$ of serum for $12 \mathrm{hr}$ at $4{ }^{\circ} \mathrm{C}$. After incubation, the supernatant was tested by P-ELISA using lysed $M$. pulmonis as an antigen for detection.

\section{Results}

Isolation of recombinant clones : It was shown by preliminary experiments that $M$. pulmonis DNA contained numerous restriction sites for HindIII. Therefore, the DNA library was constructed by inserting $M$. pulmonis DNA partially digested with HindIII into the plasmid vector $\mathrm{pUC} 19$. Approximately $3 \times 10^{3}$ transformants were obtained, and about $85 \%$ of the clones were found to be recombinants by inactivation of $\beta$-galactosidase. After screening for the expression of $M$. pulmonis antigens by colony immunoassay using anti-M. pulmonis serum, 10 clones which showed a strong positive signal were selected.

Characterization of $M$. pulmonis antigens produced in recombinants : Western blot analysis was employed to characterize the $M$. pulmonis antigens produced in recombinant clones. The antigens reacting with anti- $M$. pulmonis serum were detected in the lysates of all, 10 recombinants (Fig. 1). Seven clones (clones $1,2,3,6,7,9$, and 10) produced the 45kilodalton $(\mathrm{kDa})$ and $42-\mathrm{kda}$ antigens, 2 clones (clones 4 and 5) produced the 42-kDa and 37$\mathrm{kDa}$ antigens, and 1 clone (clone 8 ) produced the $43-\mathrm{kDa}$ and $40-\mathrm{kDa}$ antigens reacting strongly. None of the components that react with this antiserum was detected in the lysate of control $E$. colicarrying nonrecombinant pUC 19 . These recombinant antigens were also produced in the absence of IPTG.

Analysis of cloned M. pulmonis DNA fragments : The plasmid DNA isolated from the 10 clones producing the $M$. pulmonis antigens were digested with HindIII, and the size of DNA inserts was determined by agarose gel electrophoresis (Fig. 2). These clones contained the 3.7 to $6.5-\mathrm{kbp}$ DNA inserts and all clones carried the 2.3-kbp HindIII-fragment. The 1.4kbp HindIII-fragment was also included in the

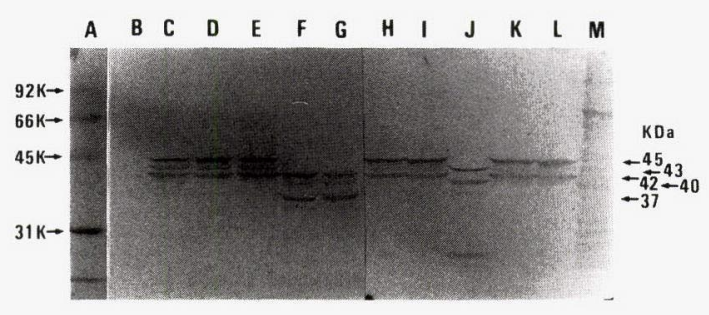

Fig. 1. Western blot analysis of recombinant antigens expressed in E. coli. The blots of whole cell lysates from control E. coli carrying pUC 19 (lane B), recombinant $E$. coli clones 1-10 (lane C-L), and $M$. pulmonis (laneM) were reacted with anti-M. pulmonis serum. Lane A shows the molecular weightst andards.

7 clones that produced the $45-\mathrm{kDa}$ and $42-\mathrm{kDa}$ recombinant antigens, and the 1.6 -kbp HindIIIfragment was inserted into the 3 clones that produced recombinant antigens of a slightly smaller size than the above-mentioned 7 clones.

Partial restriction mapping and subcloning

: Partial restriction mapping was conducted on the 3 clones (clones 3,5 , and 8 ) that produced recombinant antigens of different molecular weights (Fig. 3-1, 2 and 3). BamHI, EcoRI, HindIII, KpnI, PstI, SacI, SalI, SmaI, and XbaI were used for restriction endonuclease digestion, but DNA inserts of these 3 clones did not contain BamHI, KpnI, PstI, Sall, and SmaI sites. The 2.3-kbp HindIII-fragments in all 3 


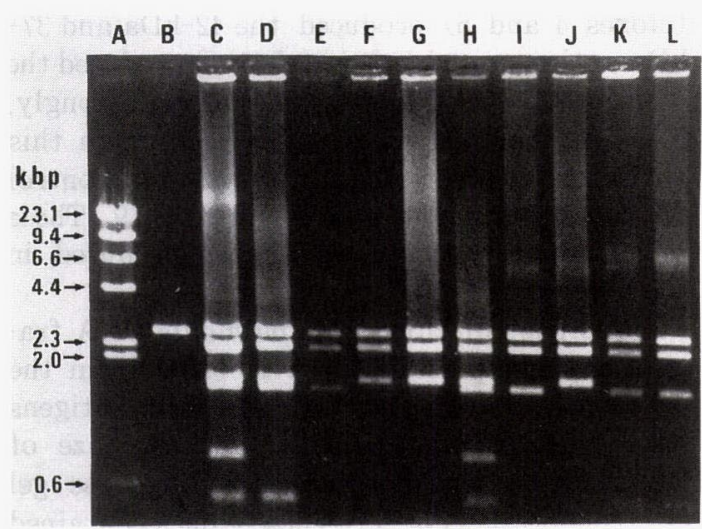

Fig. 2. HindIII restriction analysis of recombinant plasmid DNA Lane A : HindIII-digests of $\lambda$ phage DNA as size markers Lane B : pUC 19 DNA digested with HindIII Lanes C$\mathrm{L}$, recombinant plasmid DNA from clones $1-10$ digested with HindIII. Each sample was electrophoresed on a $1 \%$ agarose gel and stained with ethidium bromide.

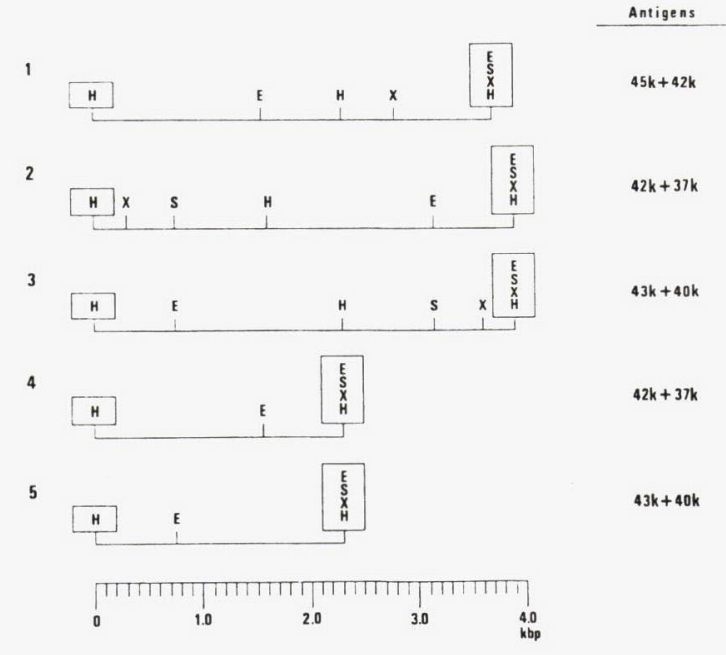

Fig. 3. Partial restriction maps of original clones and subclones expressing recombinant antigens. 1 , clone $3 ; 2$, clone $5 ; 3$, clone $8 ; 4$ and 5 , subclones inserted the same 2. $3-\mathrm{kbp}$ DNA fragment in opposite orientation. E, EcoRI ; $\mathrm{H}$, HindIII ; S, SacI ; X, XbaI. Restriction sites present in the vector DNA are shown within boxes. The molecular weights of recombinant antigens expressed by each clone are shown in the right column.
(A)

(B)

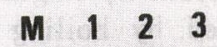

$\begin{array}{lll}1 & 2 & 3\end{array}$

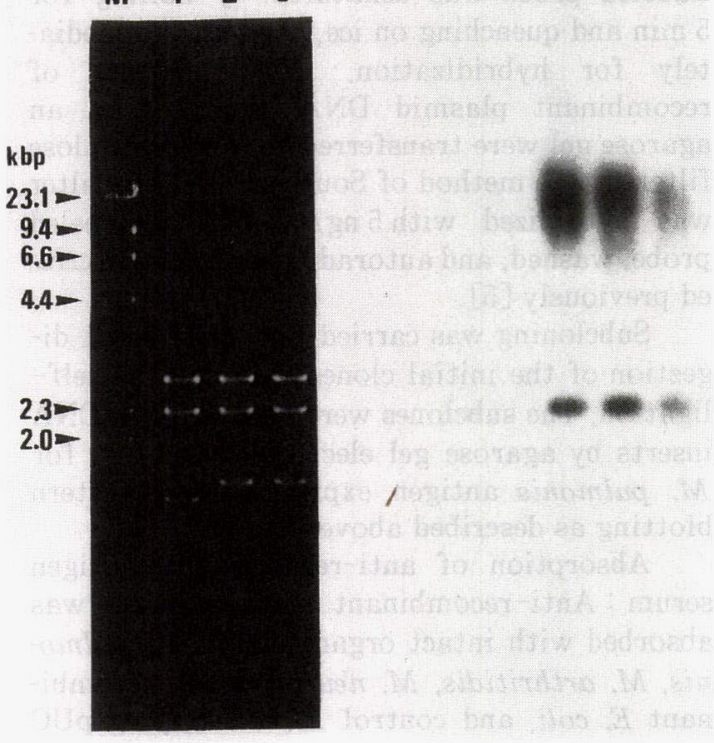

Fig. 4. Southern hybridization of the 2.3-kbp DNA insert (A): The plasmid DNA isolated from recombinant clones 3,5 and 8 (lanes 1, 2, and 3 , respectively) was digested with HindIII and electrophoresed on a $1 \%$ agarose gel. Lane $\mathrm{M}$ contains HindIII-digests of $\lambda$ phage DNA as size markers. (B) : The DNA bands were transferred to a nitrocellulose filter and probed with ${ }^{32} \mathrm{P}$-labeled 2. 3-kbp DNA insert from clone 3 .

clones contained the identical EcoRI site. In clones 5 and 8, a 3.9-kp DNA fragment containing the same restriction sites was inserted in the opposite orientation. The 2.3-kbp HindIIIfragment from clone 3 was used as a probe for Southern hybridization against the HindIIIdigested plasmid DNA from clones 3,5 , and 8 . It was found that the $2.3-\mathrm{kbp}$ inserts in these clones were identical (Fig. 4).

Furthermore, to identify the DNA fragments coding the recombinant antigens, HindIII-digested initial inserts of clones 3,5 , and 8 were subcloned. All of the subclones containing a 2.3-kbp HindIII-fragment from each clone produced recombinant antigens, and the molecular weights of these antigens were the same as those produced in clone 5 or 8 , depending on the direction of the DNA insert (Fig, 3-4 and 


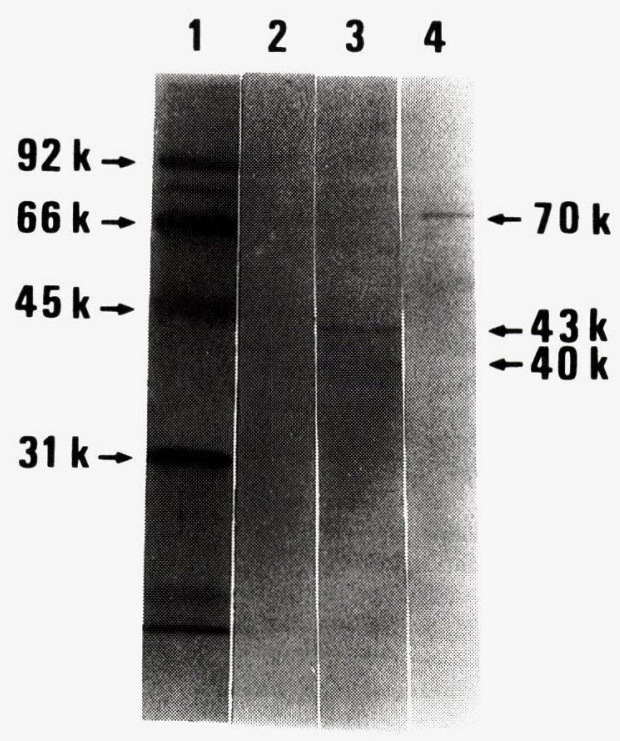

Fig. 5. Western blot analysis of a native $M$. pulmonis antigen using anti-recombinant antigen serum. The blots of whole cell lysates from control E. coli carrying pUC19 (lane 2), recombinant $E$. coli carrying the $2.3-\mathrm{kbp} M$. pulmonis DNA (lane 3), and M. pulmonis (lane 4) were reacted with antiserum against the recombinant antigens generated from the 2. 3-kbp M. pulmonis DNA. Lane 1 shows the molecular weight standards.

5). On the other hand, in the subclones in which a $1.4-\mathrm{kbp}$ or 1.6 -kbp HindIII-fragment was inserted, the expression of recombinant antigens was not detected.
Identification of native $M$. pulmonis antigens related to recombinat antigens : In order to identify the native $M$. pulmonis antigens related to the recombinant antigens generated from the 2.3-kbp HindIII-fragment, Western blot analysis was conducted by using antiserum against the recombinant antigens expressed in E. coli carrying the 2.3-kbp insert (Fig. 5). This antiserum reacted specifically with the recombinant antigens, but did not react with the control $E$. coli carrying nonrecombinant pUC 19. A $70-\mathrm{kDa}$ antigen of $M$. pulmonis was recognized by this antiserum.

Further, in order to confirm the specificity of the recombinant antigens, an absorption test was conducted. As shown in Table1,the reactivity of anti-recombinant antigen serum was significantly reduced after absorption with $M$. pulmonis and recombinant $E$. coli carrying the 2.3-kbp insert, but after absorption with $M$. arthritidis, $M$. neurolyticum and control $E$. coli carrying pUC 19, there was no change in this reactivity.

\section{Discussion}

To obtain the DNA fragment which codes an antigen specific for $M$. pulmonis, genomic DNA derived from $M$. pulmonis $\mathrm{m} 53$ was cloned and screened for antigen expression in $E$. coli. As a result, recombinant clones which reacted specifically with anti- $M$. pulmonis serum were obtained, and in these clones, the seroreactive antigens seemed to be expressed from $M$. pulmonis DNA fragments inserted in

Table 1. Effect of absorbing anti-recombinant antigen serum with intact organisms on ELISA ${ }^{11}$

\begin{tabular}{lc}
\hline Treatment of serum & Inhibition $(\%)^{2)}$ \\
\hline$(-)$ & 0 \\
M. pulmonis & 77.6 \\
M. arthritidis & 3.9 \\
M. neurolyticum & 1.1 \\
Recombinant E. coli ${ }^{3)}$ & 74.5 \\
Control E. coli & 3.4 \\
\hline
\end{tabular}

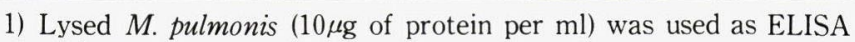
antigen

2) Inhibition $(\%)=\frac{O D \text { value of unabsorbed serum }-O D \text { value of absorbed serum }}{O D \text { value of unabsorbed serum }} \times 100$

3) E. coli carrying the 2.3-kbp $M$. pulmonis DNA

4) E. coli carrying nonrecombinant pUC19 
a plasmid vector. Regarding the expression of mycoplasmal antigens in $E$. coli, both successes and failures in autonomous expression by mycoplasmal promoters have been reported [3, $4,14]$. In this study, $M$. pulmonis antigens were expressed in $E$. coli even without a lac inducer, IPTG. This finding indicates that the promoters of $M$. pulmonis can also function in E. coli.

In order to identify the DNA fragment coding the $M$. pulmonis antigens expressed in $E$. coli, DNA inserts of the recombinant plasmids were analyzed. The results of restriction digestion and Southern hybridization indicated that the recombinant plasmids contained a 2 . 3-kbp DNA fragment as a common sequence. In addition, the examination for $M$. pulmonis antigen expression in subclones showed that recombinant antigens were produced only in $E$. colicarrying the 2.3-kbp DNA fragment, which seems to be an essential fragment for antigen expression.

In addition, the specificity of the antigen coded by the $2.3-\mathrm{kbp}$ DNA fragment was analyzed by using antiserum against the recombinant antigen. Antiserum which reacted specifically with the recombinant antigen expressed in $E$. coli also reacted with the 70$\mathrm{kDa}$ component in $M$. pulmonis lysate. Therefore, the recombinant antigen was considered to be related to a native $M$. pulmonis antigen. Moreover, although serological cross-reactivity between $M$. pulmonis and $M$. arthritidis has been noted [8], antibodies to the recombinat antigen were specifically absorbed by $M$. pulmonis but were not absorbed by $M$. arthritidis and $M$. neurolyticum. These results suggest that the recombinant antigen expressed from the 2.3-kbp fragment of $M$. pulmonis DNA has specificity for $M$. pulmonis.

In conclusion, we succeeded in obtaining a 2.3-kbp DNA fragment coding the speciesspecific antigen of $M$. pulmonis. This DNA fragment may be used by itself as a DNA probe for the detection and identification of M. pulmonis.

This work was partly supported by a Grant-in-Aid for Scientific Research (No. 63780060) from the Ministry of Education, Science and Culture, Japan.

\section{References}

[1] Birnboim, H. C. and Doly, J. (1979). A rapid alkaline extraction procedure for screening recombinant plasmid DNA. Nucleic Acids Res., 7, 1513-1523.

[2] Helfman, D. M., Feramisco, J. R., Fiddes, J. C., Thomas, G. P., and Hughes, S. H. (1983). Identification of clones that encode chicken tropomyosin by direct immunological screening of a cDNA expression library. Proc. Natl. Acad. Sci. USA 80, 31-35.

[3] Kawauchi, Y., Muto, A., Yamao, F., and Osawa, S. (1984). Molecular cloning of ribosomal protein genes from Mycoplasma capricolum. Mol Gen. Genet., 196, 521-525.

[4] Klinkert, M.-Q., Herrmann, R., and Schaller, H. (1985). Surface proteins of Mycoplasma hyopneumoniae identified from an Escherichia coli expression plasmid library. Infect. Immun. 49, 329-335.

[5] Kunita, S., Terada, E., Ghoda, A., Takakura, A., and Kagiyama, N. (1989). Genomic DNA analysis of rodent mycoplasmas. Exp. Anim, 38, 201-206.

[6] Laemmli, U. K. (1970). Cleavage of structural proteins during the assembly of the head of bacteriophage T 4. Nature (London), 227, 680-685.

[ 7 ] Maniatis, T., Fritsch, E. F., and Sambrook, J.(1982). Molecular cloning, In a laboratory manual. Cold Spring Harbor Laboratory, Cold Spring Harbor, N. Y.

[8] Minion, F. C., Brown, M. B., and Cassell, G. H. (1984). Identification of cross-reactive antigens $^{-}$ between Mycoplasma pulmonis and Mycoplasma arthritidis. Infect. Immun., 43, 115-121.

[9] Southern, E. (1975). Detection of specific sequences among DNA fragments separated by gel electrophoresis. J. Mol Biol, 98, 503-517.

[10] Takakura, A., Kagiyama, N., Sakurai, Y., Suzuki, H., Kobayashi, N., and Terada, E. (1988). Detection of Sendai virus antibody in mouse and guinea pig sera by an enzyme-linked immunosorbent assay with proteinA. Exp. Anim, 37, 279-283.

[11] Towbin, H., Starhelin, T., and Gordon, J. (1979). Electrophoretic transfer of proteins from polyacry lamide gels to nitrocellulose sheets : procedure and some application. Proc. Natl Acad. Sci USA 76, 4350-4354.

[12] Watson, H. L., Davidson, M. K., Cox, N. R., Davis, J. K., Dybvig, K., and Cassell, G. H. (1987). Protein variability among strains of Mycoplasma pulmonis. Infe ct.Immun, 55, 2838-2840.

[13] Weislander, L. (1979). A simple method to recover intact high molecular weight RNA and DNA after electrophoretic separation in low gelling temperature agarose gels. Anal Biochem, 98, 305-309.

[14] Wise, K. S. (1984). Antigen expression from cloned genes of Mycoplasma hyorhinis : an approach to mycoplasma genomic analysis. Isr. J. Med. Sci, 20 , 754-757.

[15] Yanisch-Perron, C., Vieira, J., and Messing, J. (1985). Improved M 13 phage cloning vectors and host strains : nucleotide sequences of the M 13 mp 18 and pUC 19 vectors. Gene, 33, 103-119. 


\title{
Mycoplasma pulmonis 抗原の大腸菌に扣ける発現
}

国田智・寺田英司・合田朗・桜井美典*

鈴木宏和*・高倉彰**・鍵山直子**

\author{
北里大学衛生学部実験動物学研究室 \\ *わかもと製薬株式会社 \\ **(財) 実験動物中央研究所
}

Mycoplasma pulmonis m53 株由来のゲノム DNA をクローニングし，大腸菌に批る M. pulmonis抗原 の発現ならびに抗原発現に関与寸る DNA 断片つ同定 を行った。抗 M. pulmonis血清を用いたコロニー・イ ムノアッセイにより M. pulmonisの DNA ライブラリ 一をスクリーニングしたところ，本抗血清と反応する抗 原を発現している10個のクローンが得られた。これらの クローンから分離された組換えプラスミドには3.7-6.5 キロベースペア $(\mathrm{kbp})$ の DNAが插入されており，す
べてのクローンが 2. 3-kbp の DNA 断片を有していた。 插入 DNAをサブクローニングしたところ, 共通に存 在する 2. 3-kbp の DNA 断片が抗原発現には不可欠で あることが判明した。また，2.3-kbp の DNAから発現 した組換え抗原に対する抗血清は M. pulmonis 由来の 抗原を認識し, その反応性は M. pulmonisによって特 異的に吸収された。以上の成績より，クローン化された 2. 3-kbp の DNA 断片は M. pulmonis に特異的な抗 原をコードしていることが示唆された。 